

Research Article

\title{
Red mud reinforced polyvinyl alcohol composite films: synthesis, chemical, mechanical and thermal properties
}

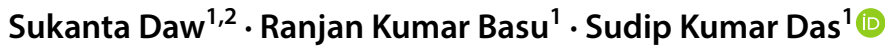

(c) Springer Nature Switzerland AG 2019

\begin{abstract}
Nowadays biodegradable polymer draws much attention to the researcher compared to the petroleum-based nonbiodegradable polymer due to the environmental and energy crisis. Aluminum industry waste red mud (RM) reinforced with polyvinyl alcohol (PVA) organic-inorganic composite film was synthesized by sol-gel method. The effects of sodium lauryl sulfate (SLS) as a compatibilizer on the composite were investigated. The composites were characterized by UV absorption, Fourier transforms infrared spectrophotometer (FTIR), X-ray diffraction, scanning electron microscopy (SEM), EDX. Chemical, mechanical and thermal properties of the composites were investigated with different amount of red mud-PVA and also the comparison between them without and with SLS addition. Physical and chemical bonding in the PVA, PVA-RM, and PVA-RM-SLS were shown through FTIR spectra. SEM images exhibit excellent compatibility between PVA and RM in the composite. Degree of swelling and tensile strength were increased by $71.48 \%$ and $194.88 \%$ respectively, and again percentage of elongation at break and solubility were decreased by $98.07 \%$ and $78.07 \%$ respectively for the PVA-RM-SLS composite compared to virgin PVA. TGA thermogram reveals that PVA-RM-SLS system had more thermal stability than pure PVA. All the results showed excellent adhesion between PVA and red mud and established the effect of RM as filler and SLS as compatibilizer. This composite is suitable as packaging materials.
\end{abstract}

Keywords PVA · Red mud·Sodium lauryl sulfate $\cdot$ Sol-gel $\cdot$ Compatibilizer

\section{Introduction}

In the last few decades, researchers have been searching to minimize the usability of petroleum-oriented product and fuels due to the increase in environmental pollution and limited sources of petroleum. Petroleum-based synthetic polymer like polyethylene, polypropylene, ethylene-propylene, polyethylene terephthalate, polystyrene, polybutadiene, acrylonitrile-butadiene-styrene, etc. is often nonbiodegradable. These materials have been greatly using in various fields of engineering and also human activities. In the last decade, researchers are involved in developing bio-degradable polymers with base materials like cellulose, starch, and proteins [1-3]. Polyvinyl alcohol (PVA), starch and cellulose particle film were developed with the addition of nanoparticle for packaging application $[4,5]$.

Renewable biopolymers, like proteins, lipid and polysaccharides can be formed into either stand-alone films or coatings. The primary advantages of using these films are environmentally friendly regarding recyclables and utilization to compare to the conventional synthetic polymeric film. Scientists have concentrated their research on ecocomposite materials due to strong rules and regulations for a safer and cleaner environment $[6,7]$.

Polyvinyl alcohol (PVA) can be used as a water-processable polymer. It is used in a different industry for its exclusive physical and chemical properties [8, 9]. In PVA structure the hydroxyl groups combine to methane carbons

Sudip Kumar Das, drsudipkdas@vsnl.net; skdchemengg@caluniv.ac.in | Department of Chemical Engineering, University of Calcutta, 92, A. P. C. Road, Kolkata, West Bengal 700 009, India. ${ }^{2}$ Department of Polymer Science and Technology, University of Calcutta, 92, A. P. C. Road, Kolkata, West Bengal 700 009, India. 
with the carbon chain backbone. To form the polymer complex assist with hydroxyl group may be a source of hydrogen bonding [10]. Polyvinyl alcohol is a highly hydrophilic, crystalline, water-soluble, biodegradable, low-cost and non- toxic polymer. It is used in the packaging industry because of its excellent chemical and thermal stability, mechanical strength and great film-forming properties. PVA is a water-soluble polymer, so it has to be entirely transferred into the insoluble material for used in the treatment of wastewater with excellent mechanical properties. The various properties like high modulus of elasticity and abrasion resistance etc. superior to pure organic polymers are obtained by incorporating inorganic materials in the polymer backbone.

The composite materials are the combination of polymer and fillers exhibit the resistance of heat, small gas permeability, flammability and high modulus strength in comparison with the single polymer [11]. The aspect ratio, volume fraction, filler's size and distribution and the intrinsic compatibility between the filler and matrix surfaces of the composites have an essential factor on the mechanical characteristics [12]. The yield strength of the composite generally increases for the large aspect ratio (fiber type) because of substantial local stress is transferring from the polymer matrix by the filler [13]. The selection of surface functional groups influences the creation of interfacial interactions with filler and polymer and can guide the construction of greater utility polymer composites. The mixing of filler, such as starch [14], clay [15], sugarcane [16], wood dust [17], $\mathrm{TiO}_{2}$ [18], cement [19], organo-ceramics [20] and carbon nanotubes [21] with PVA is a modern technique for the development of biodegradable composite. PVA composites have broad applications in the food packaging by film [22] and in optical holography fiber [23], sizing and finishing in textile industries, adhesives, coatings, emulsifiers, colloidal stabilizers, solar cell [18] and fuel cell [24].

Red mud is generated through Bayer's process for the producing of aluminum from bauxite in the aluminum industry. It is the main waste material originating 30 million tons every year around the world [25]. The most crucial factors about red mud are the cost of disposal, pollution and entail space abort industrial region. Therefore, the utilization of this by-product is one of the leading technological concerns of environment and industries and its recycling for other products [26]. Composite material composed of PVA as matrix and red mud as filler drawing interest to the researcher in recent time because of their unique characteristics and generate different types of industrial application. For the small amount of clay loading in the PVA matrix, mechanical, thermal [27, 28], flame radiant [29], corrosion protection [30-32] and molecular barrier [33] properties of the composites were developed. Researchers have been suggested that red mud may be used as low-cost filler for polymer composites or as an adsorbent for the removal of heavy metals from wastewater [34]. The abrasive wear and mechanical properties of the polymer were developed using red mud as filler $[35,36]$. Activated red mud was used as a good adsorbent for phosphate and chromium adsorption [37]. Bhat and Bhatia were synthesized PVA/red mud (modified) composite and analyzed the different properties of it $[25,38]$.

However, the character of the composites deteriorated due to the increase in filler content in the composite. It happens because of less compatibility between matrix and filler and phase separation during composite preparation. The compatibility between PVA and different filler can be improved with the incorporation of proper cross-linking agents [2,39], plasticizers [40], fillers $[41,42]$, and compatibilizers.

The main objective of this work is the utilization of aluminum industry waste red mud as low-cost filler in PVA matrix and enhances it's chemical, mechanical and thermal properties for different industrial application mainly packaging industry. To investigate the effect of SLS as compatibilizer on the films for better compatibility between the PVA and red mud and also enriches the properties of the organic-inorganic composite films. The present work describes the synthesis of PVA-red mud composites films without and with compatibilizer using the sol-gel method. Sodium lauryl sulfate was used as compatibilizer. The morphology, element distribution, transparency and functional groups of the composites were characterized using SEM, EDX, and UV-Vis and FTIR spectra respectively. The role of red mud as a filler and sodium lauryl sulfate as a compatibilizer on the chemical properties such as the degree of swelling, solubility and boiling water resistance of the composites were investigated. Mechanical and thermal properties of the composites were also investigated.

\section{Experimental}

\subsection{Materials}

Polyvinyl alcohol was obtained from Central Drug House (P) LTD; Mumbai, India having the molecular weight of 14,000 with $99 \%$ hydrolyzed and water solution $\mathrm{pH}$ is about 5-7. Red Mud was collected from Nalco, Damanjodi, Odisha, India with particle size-100+120 Mesh. Sodium Lauryl Sulfate (SLS) [98\%, $\left.\mathrm{CH}_{3}\left(\mathrm{CH}_{2}\right)_{11} \mathrm{OSO}_{3} \mathrm{Na}\right]$ was obtained from Merck Specialties Private Limited. Mumbai, India with molecular weight 288.38 , the anionic surfactant of $\min 2.903 \mathrm{mval} / \mathrm{g}$ and $1 \%$ solution $\mathrm{pH}$ is 6-9. 


\subsection{Synthesis of PVA-red mud composite films}

Sol-gel technique synthesized PVA-red mud composite films. Firstly, $5 \mathrm{~g}$ of PVA was mixed with $100 \mathrm{ml}$ of distilled water at around $80^{\circ} \mathrm{C}$. The mixture was stirring until a clear solution was obtained. Two types of gels were prepared, namely without SLS and with SLS.

Red mud in the wt\% of $2,4,6,8,10,20,30,40$ and 50 concerning PVA in nine different batches was mixed to the above solution. Each mixture was continuously stirring in a mechanical stirrer (500 rpm) at normal temperature for $30 \mathrm{~min}$. In this way, nine gel samples were prepared.

On the other hand, $1 \mathrm{wt} \%$ of Sodium lauryl sulfate concerning $0.1,0.2,0.3,0.4,0.5,1.0,1.5,2.0$, and $2.5 \mathrm{~g}$ of red mud in nine different batches was added to red mud. By adding a small amount of distilled water in different batches, the thick solution was prepared. Each of this solution was added to the $100 \mathrm{ml} 5 \%$ solution of PVA at the room temperature under the same stirring condition as done previously.

Finally, these eighteen gel samples and the control were cast over thoroughly cleaned smooth glass plate covered with the thick transparent sheet and kept in the open atmosphere to evaporate the water for several days till they have no weight variation. The films were then dried at $50-60^{\circ} \mathrm{C}$ about $8 \mathrm{~h}$ and the composites were ready for use. The composition of each sample and its name has been listed in Table 1.

\subsection{Characterization}

The film thickness is a very important parameter of the composites regarding its ranges of applications and the feasibility of the film. In this work, the thickness was measured by the thickness measuring instrument, supplied by M/S S. C. Dey \& Co. Kolkata, India.

Hydrostatic balance determines the specific gravity of the films. The weight in air divided by the loss of weight in water is equal to the specific gravity of the film.

The optical density $(O D)$ in the ultraviolet and visible range of the composite films was estimated through absorbance $(A)$ value. If $I_{o}$ and $I$ were the incidents and transmitted intensity of light respectively for the film thickness, $t$ then Optical Density $(O D)$, is given by

$O D=A=\log \left(\frac{I_{0}}{I}\right)=\log \left(\frac{1}{T}\right)=-\log T$

The values of Absorbance for 100-micrometer thickness for each were compared.

FTIR spectrophotometer (Model-Nicolet iS5, Thermo Fisher Scientific, USA) was used to determine the

Table 1 Composition of various gels of PVA and red mud without and with SDS

\begin{tabular}{|c|c|c|c|c|c|c|}
\hline Sl. no. & Sample name & $\begin{array}{l}\text { PVA in } \\
100 \mathrm{ml} \text { water } \\
\text { (g) }\end{array}$ & Red mud (g) & $\begin{array}{l}\text { Percentage of red mud with } \\
\text { respect to the weight of the solid } \\
\text { PVA }\end{array}$ & $\begin{array}{l}\text { Sodium lauryl sulphate ( } 1 \% \\
\text { of weight of red mud) (g) }\end{array}$ & Thickness $(\mu \mathrm{m})$ \\
\hline 1 & PVA & 5 & 0 & 0 & - & 100 \\
\hline 2 & PVARM2 & 5 & 0.1012 & 2 & - & 85 \\
\hline 3 & PVARM4 & 5 & 0.2016 & 4 & - & 89 \\
\hline 4 & PVARM6 & 5 & 0.3021 & 6 & - & 105 \\
\hline 5 & PVARM8 & 5 & 0.4019 & 8 & - & 100 \\
\hline 6 & PVARM10 & 5 & 0.5013 & 10 & - & 120 \\
\hline 7 & PVARM20 & 5 & 1.0024 & 20 & - & 115 \\
\hline 8 & PVARM30 & 5 & 1.5017 & 30 & - & 95 \\
\hline 9 & PVARM40 & 5 & 2.0023 & 40 & - & 105 \\
\hline 10 & PVARM50 & 5 & 2.5014 & 50 & - & 105 \\
\hline 11 & PVARM2C & 5 & 0.1022 & 2 & 0.0011 & 55 \\
\hline 12 & PVARM4C & 5 & 0.2013 & 4 & 0.0023 & 70 \\
\hline 13 & PVARM6C & 5 & 0.3023 & 6 & 0.0032 & 60 \\
\hline 14 & PVARM8C & 5 & 0.4016 & 8 & 0.0041 & 85 \\
\hline 15 & PVARM10C & 5 & 0.5021 & 10 & 0.0053 & 95 \\
\hline 16 & PVARM20C & 5 & 1.0023 & 20 & 0.0105 & 105 \\
\hline 17 & PVARM30C & 5 & 1.5027 & 30 & 0.0157 & 75 \\
\hline 18 & PVARM $40 C$ & 5 & 2.0013 & 40 & 0.0207 & 90 \\
\hline 19 & PVARM50C & 5 & 2.5023 & 50 & 0.0253 & 100 \\
\hline
\end{tabular}


functional groups present in the composite in the wavelength range $4000 \mathrm{~nm}$ to $400 \mathrm{~nm}$ with $4 \mathrm{~cm}^{-1}$ resolution.

The composite films were characterized by PAN Analytical XRD Instruments (Almelo Netherlands) using the $\mathrm{Cu} \mathrm{Ka}$ radiation generated from $\mathrm{Cu} \mathrm{X}$-ray tube. The films were scanned from $10^{\circ}$ to $70^{\circ}$ with $2^{\circ} \mathrm{min}^{-1}$ scan rate and measuring the Bragg angle $2 \theta$.

The morphology of PVA, PVARM8, PVARM20, PVARM8C, and PVARM20C were analyzed by using the Scanning Electron microscopy (SEM) (CARL ZEISS EV018 special edition Germany). The specimen for the PVA-Red mud composites were cooled in liquid nitrogen mounted and coated with platinum.

EDX (EDX Oxford instrument INCA Penta FETX3 ModelEDS 8100 England) was applied to detect the element distribution profile on the external surface of the membrane

In the swelling test the osmotic swelling phenomenon of the films was considered. Here the degree of swelling is compared among the films in which about $0.1 \mathrm{~g}$ of each film is allowed to be soaked in about $50 \mathrm{ml}$ of water for $24 \mathrm{~h}[4]$. If $\left(W_{i}\right)$ and $\left(W_{f}\right)$ are the weights before and after swelling respectively then equilibrium-swelling index as percentage basis is giving by the following formula.

$\alpha=\left[\frac{\left(W_{f}-W_{i}\right)}{W_{i}}\right] \times 100$

The following way observed the solubility test. First, the films were dried at $60^{\circ} \mathrm{C}$ and then the weight $\left(W_{1}\right)$ of the films was taken. After this, the films were kept inside the water for $24 \mathrm{~h}$ at room temperature [5]. Again films were dried at $60^{\circ} \mathrm{C}$ and measured the weight $\left(W_{2}\right)$ of the films. Percentage of solubility ware calculated by the following formula,

$S=\left[\frac{\left(W_{1}-W_{2}\right)}{W_{1}}\right] \times 100$

The boiling test in water gave the measure of the hydrothermal stability of the film. Heat energy was supplied to the system to observe the stability of the system at a higher energy level. In this test about $0.2 \mathrm{~g}$ of the film was added to the boiling distilled water $\left(100^{\circ} \mathrm{C}\right)$ and the dissolution characteristics of the film were observed. It was seen that all the samples were going into the solution but the time taken by them were different from one another. Time taken to go into the solution was recorded in each case by using a stopwatch and data obtained were compared for $1 \mathrm{~g}$ of films.

Tensile strength (TS), percentage of elongation at break (\%E) and Young modulus (YM) were estimated for all composite (Lloyd 10K + Universal material testing machine
Ametek Company England) and ASTM-D-A 638 specification. Eleven rectangular shaped samples were having length $110 \mathrm{~mm}$, width of $15 \mathrm{~mm}$ and thickness about $0.1 \mathrm{~mm}$. Both gauge length and grip distance were $50 \mathrm{~mm}$ with $250 \mathrm{~kg}$ load cell. The temperature and relative humidities were $28^{\circ} \mathrm{C}$ and $60 \%$ respectively at the time of the test.

Thermogravimetric analysis of PVA—Red mud composite films were performed using DTH-60H SHIMADZU in the nitrogen atmosphere with the temperature range from 28 to $600^{\circ} \mathrm{C}$ with the heating rate of $10^{\circ} \mathrm{C} / \mathrm{min}$.

\section{Results and discussion}

\subsection{Preparation}

The thickness of the composite films was reported in Table 1.The average thickness of all the films was $100 \mu \mathrm{m}$.

Specific gravity was increased as the percentage of red mud was increased according to Fig. 1, and the maximum percentage of increase was 34.25 and 36.66 with and without SLS respectively as shown in Table 2 . An increase in the specific gravity of the films is due to the enhancement of compactness as more cross-links in the structure were found.

\subsection{Microstructure}

Optical densities of the composite films using UV-Vis spectrometer were reported in Figs. 2 and 3. As wt $\%$ of red mud loading was increased in PVA composite Absorbance value

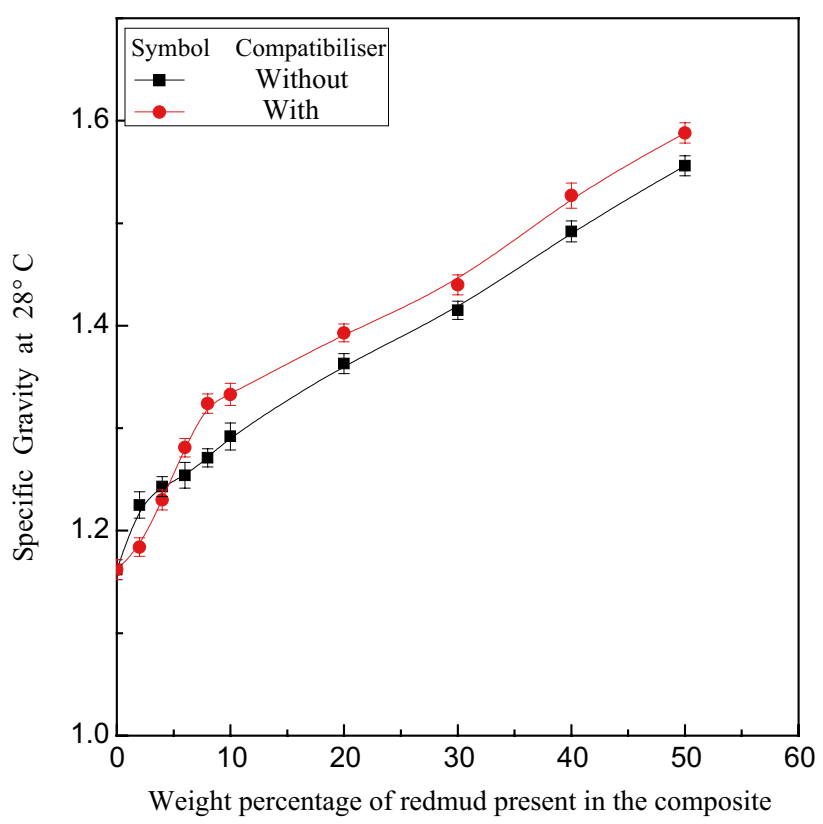

Fig. 1 Study of the trend of specific gravity of the composite films 
Table 2 Maximum and minimum change in percentage of the chemical and mechanical properties of the composite

\begin{tabular}{lcccrrrr}
\hline Test & Neat PVA film & $\begin{array}{l}\text { PVARM film, } \\
\text { max or min } \\
\text { value }\end{array}$ & $\begin{array}{l}\text { Change value with } \\
\text { respect to neat PVA }\end{array}$ & $\begin{array}{l}\text { Change in } \\
\text { percentage }\end{array}$ & $\begin{array}{l}\text { PVARMSLS } \\
\text { film, max } \\
\text { vale }\end{array}$ & $\begin{array}{l}\text { Change value } \\
\text { percentage }\end{array}$ & $\begin{array}{l}\text { Change in } \\
\text { plentring }\end{array}$ \\
\hline Swelling & 308.13 & 96.67 & -211.46 & -68.63 & 87.88 & -220.25 & -71.48 \\
Solubiliy & 18.42 & 4.19 & -14.23 & -77.25 & 4.04 & -14.38 & -78.07 \\
Boiling & 41.93 & 252.87 & 211.44 & 504.27 & 271.92 & 229.99 & 548.51 \\
Sp.gravity & 1.162 & 1.556 & 0.398 & 34.25 & 1.588 & 0.426 & 36.66 \\
Tesile strength & 23.662 & 24.241 & 0.579 & 2.45 & 69.775 & 46.113 & 194.88 \\
Elongation at break (\%) & 307.084 & 46.652 & -260.432 & -84.81 & 5.913 & -301.171 & -98.07 \\
Young's modlus & 72.352 & 549.683 & 477.332 & 659.74 & 3209.716 & 3137.366 & 4336.25 \\
\hline
\end{tabular}

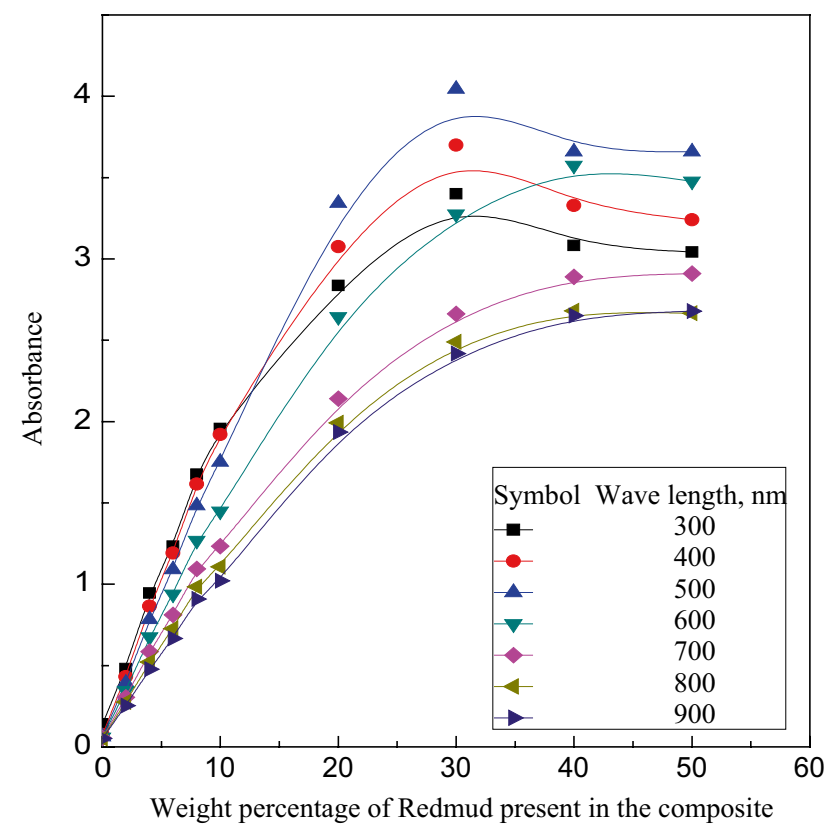

Fig. 2 Variation of absorbance with different red mud loading of the composite without using compatebiliser

is increased and went to the highest value at $30 \mathrm{wt} \%$ and $40 \mathrm{wt} \%$ loading of red mud without and with SLS respectively due to red colored material. With the increasing percentage of the red mud, the transparency and the transmittance of the films were decreased, and the absorbance was increased. It is shown from each of the seven curves that the value of the absorbance is not much affected by the addition of the compatibilizer.

The variations of absorbance with wavelength for different composites were shown in Figs. 4 and 5. The value of absorbance was continuously decreasing with the increase in wavelength for the composites from 2 to $10 \mathrm{wt} \%$ loading of red mud because of the preset of the different elements like iron and silica whereas absorbance was constant for pure PVA film. The composites with $20-50 \mathrm{wt} \%$ red mud showed a peak around $500 \mathrm{~nm}$. This peak appeared due to

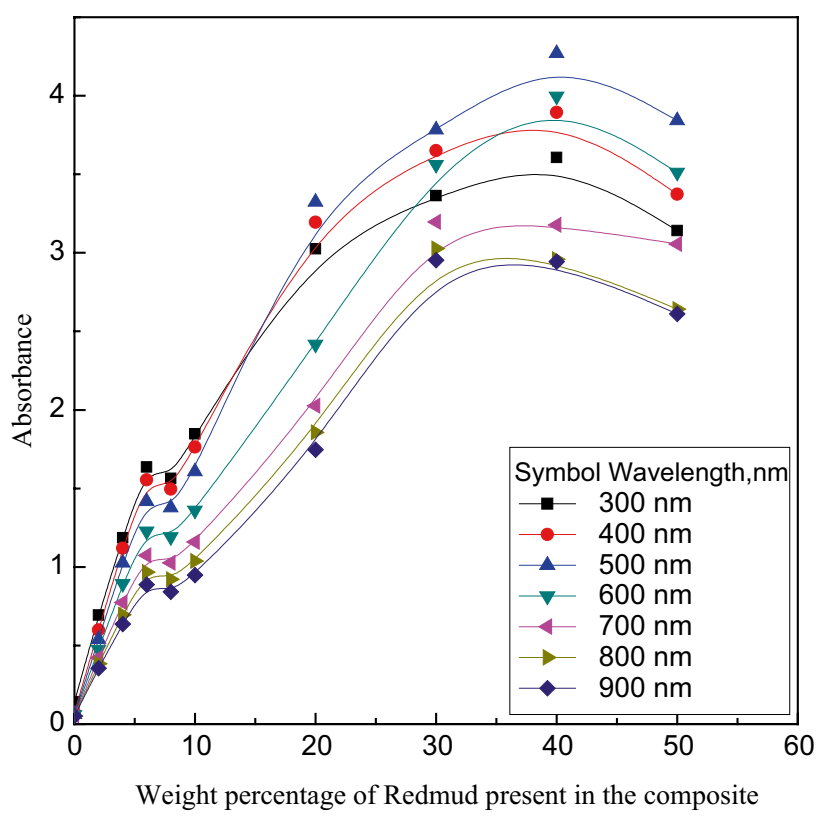

Fig. 3 Variation of absorbance with different Red mud loading of the composite using compatebiliser

iron which is the main element in the red mud. Different UV-Vis absorption peaks were reported for $\mathrm{PVA} / \mathrm{Ag}_{2} \mathrm{~S}, \mathrm{CdS} /$ PVA and Ag-PVA composites previously [43-45].

FTIR spectroscopy and spectra of pure PVA and composites were studied and illustrated in Fig. 6 and Table 3. A wide absorption was observed around $3267 \mathrm{~cm}^{-1}$ for the $\mathrm{O}-\mathrm{H}$ stretching vibrations as hydrogen bonded hydroxyl groups absorbed moisture which was present in the samples [46]. A number of absorption bands at $2915 \mathrm{~cm}^{-1}$ due to $\mathrm{C}-\mathrm{H}$ stretching and bending [47], $1719 \mathrm{~cm}^{-1}$ for $\mathrm{C}=\mathrm{O}$ stretching, $1420 \mathrm{~cm}^{-1} \mathrm{C}-\mathrm{H}$ bending vibration of $\mathrm{CH}_{2}$ group [48], $1326 \mathrm{~cm}^{-1}$ due to $C-C$ stretching vibration, $1086 \mathrm{~cm}^{-1}$ of $\mathrm{C}-\mathrm{O}$ stretching of ether group [49] were generated in pure PVA film [50]. The peaks at $3267 \mathrm{~cm}^{-1}$ for O-H stretching and $2915 \mathrm{~cm}^{-1}$ for $\mathrm{C}-\mathrm{H}$ stretching and bending in pure PVA film were moved towards the smaller wave number 


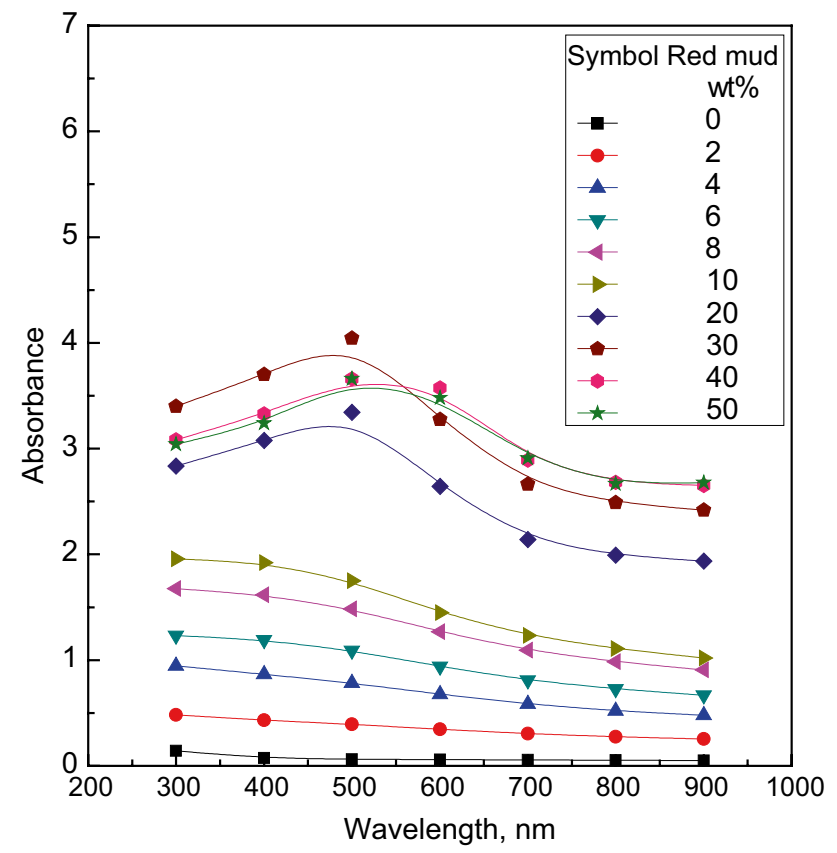

Fig. 4 Variation of absorbance with wavelengths for the composites without using compatebiliser

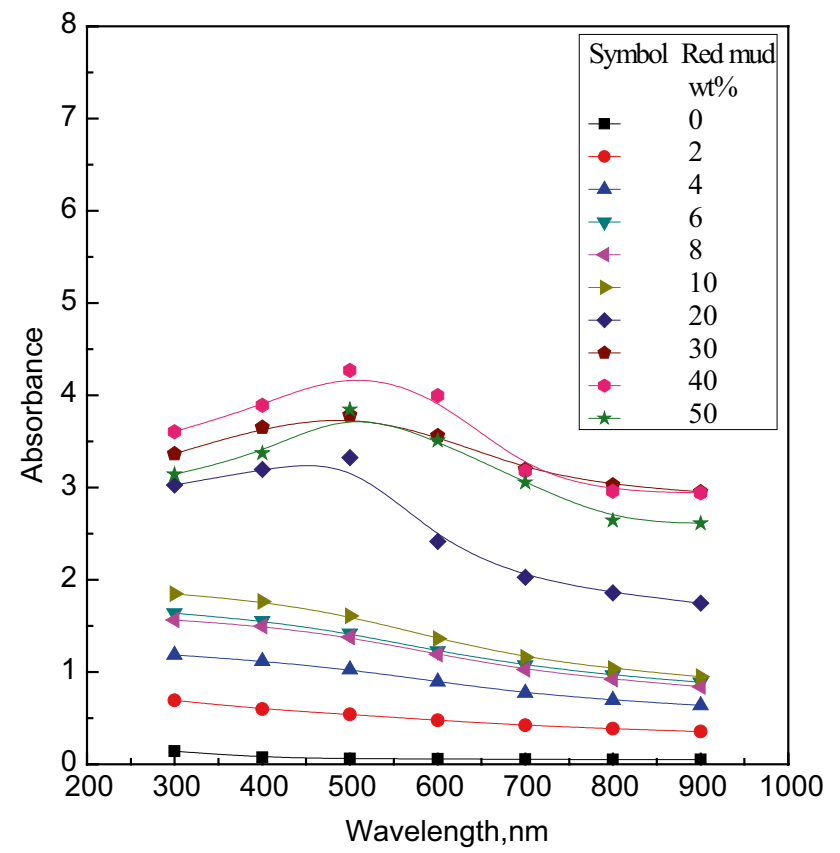

Fig. 5 Variation of absorbance with wavelength of the composite using compatebiliser

as well as slightly fewer intensities in the composites. The graph shows that there was a change in intensities and shifting of the functional group of the wave number of films relative to pure PVA. These happened due to

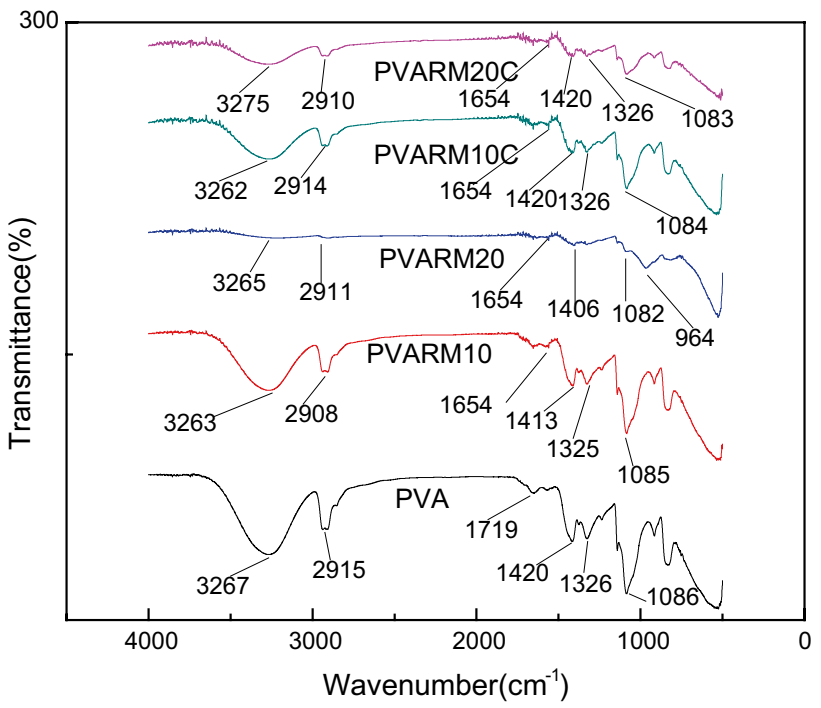

Fig. 6 FTIR spectra of the composite films

intra-molecular and inter-molecular $\mathrm{H}$ - bonding between red mud and PVA matrix.

$X$-ray diffraction is an important technique to analyze different material like ceramics, polymers, ceramics and composite materials with crystalline domains. This analysis was the comparative study of the XRD pattern between neat PVA film, and different composites which were shown in Fig. 7 and Table 4 showed the value of $2 \theta$ and $d_{100}-$ spacing of different film. Pure PVA film has limited crystallinity as it has hydrogen bond interaction which is between the hydroxyl groups. The peek at the low $2 \theta$ angle (19.580) is the most important one. The value of $2 \theta$ of neat PVA film is higher than all other composites, so the percentage of crystallinity is more significant for neat PVA film. Similar XRD results were found for $\mathrm{Ag}_{2} \mathrm{~S}$-PVA and CdS-PVA nanocomposites $[43,44]$. Angle $2 \theta$ value was increased that is the diffraction peak of the films was displaced towards the larger $2 \theta$ value and corresponding $\mathrm{d}_{100}$-spacing is decreased on the increase of the percentage of filler content. With the incorporation of SLS diffraction peak shifted to higher value and $d_{100}$-spacing goes to a lower value.

The morphology of pure PVA film was shown in Fig. 8a, b. PVA composites with red mud and red mud/SLS were an exhibit in Figs. 9a, b, 10a, b, 11a, b and 12a, b respectively. The SEM micrograph shows the dense and smooth surface of the composite. The morphological analysis clearly showed the proper mixing of red mud particle in the PVA matrix [4].

The element distribution of neat PVA and its composites were reflected in Figs. 13, 14 and 15 and Table 5. In the neat PVA film, there are two elements one is carbon, and the other is oxygen. Also of the above two elements, iron 
Table 3 Data for Fourier transform infrared absorptions of neat PVA and composite films

\begin{tabular}{llllllll}
\hline Sample & OH stretching & $\begin{array}{l}\text { C-H stretch- } \\
\text { ing/bending }\end{array}$ & C=O stretching & O-H bending & C-H bending & $\begin{array}{c}\text { C-OH stretching } \\
\begin{array}{l}\text { C=O symet- } \\
\text { ric stretching }\end{array}\end{array}$ \\
\hline PVA0 & 3267 & 2915 & 1719 & 1420 & 1326 & 1086 & 916,832 \\
PVARM10 & 3263 & 2908 & 1654 & 1413 & 1325 & 1085 & 916,832 \\
PVARM20 & 3265 & 2911 & 1654 & 1406 & 1326 & 1082 & 964,818 \\
PVARM10C & 3262 & 2914 & 1654 & 1420 & 1326 & 1084 & 917,832 \\
PVARM20C & 3275 & 2910 & 1654 & 1420 & 1326 & 1083 & 917,825 \\
\hline
\end{tabular}



Fig. 7 XRD analysis for PVA composite film

and sodium are also present in the PVA/red mud composites as these two elements are present in the red mud.

\subsection{Chemical property}

The swelling behavior of the composite was shown in Fig. 16. From the graph, it was observed that the degree of swelling (DS) was decreased with the increase of red mud content and maximum decreased were $68.63 \%$ and $71.48 \%$ without and with SLS respectively which is also shown in Table 2. This is because the swelling was more restricted as the number of cross-linked increases as the red mud forms cross-link with PVA segment. The researcher also observed that the DS decreases with the incorporation of citric acid and gluter aldehyde in starch and PVA blend film [4]. The graph also shows that there was a slight decrease in DS of the composites with SLS compared to non-SLS composites because of the increase in the compatibility between matrix and filler. The solubility of the composites was demonstrated in Fig. 17. The graph showed that solubility was decreased as the amount of red mud increased in the films and also less due to the presence of SLS. The maximum amount of decrease of the solubility was $77.25 \%$ and $78.07 \%$ without and with SLS respectively, shown in Table 2. It happened due to the number of cross-links between matrix and filler increased as the amount of red mud increased in the composites. Presence of SLS increases the compatibility as the solubility was slightly decreased. Lopez et al. [1] observed that with the increase of rosin as filler in the starch/PVA/rosin blend the solubility was decreased to $10 \mathrm{wt} \%$ of rosin loading and then increased. Yoon et al. showed that the solubility decreases with the increase of poly (methyl methacrylate co-acrylamide) in starch-PVA composite films [5]. The -OH group present in the PVA is used to form hydrogen bonding with the PVA-red mud composite, and in the presence of SLS it forms powerful cross-linking in the composite. Hence, the affinity of water for-OH group in the composites decreases, and the degree of swelling and water solubility decrease with the increase of red mud in the composite [4].
Table 4 XRD data for neat PVA film and different composites

\begin{tabular}{lllllll}
\hline SI. no & $\begin{array}{l}\text { Wt\% of red } \\
\text { mud }\end{array}$ & \multicolumn{2}{l}{ Without SDS } & & With SDS & \\
& & $2 \theta\left(^{\circ}\right)$ & $\mathrm{d}_{100}$-spacing $(\AA)$ & & $2 \theta\left(^{\circ}\right)$ & $\mathrm{d}_{100}$-spacing $(\AA)$ \\
\hline 1 & 0 & 19.580 & 4.53010 & - & - \\
2 & 8 & 18.336 & 4.83056 & 18.370 & 4.82974 \\
3 & 20 & 18.426 & 4.0815 & 18.862 & 4.70480 \\
4 & 40 & 18.690 & 4.74504 & 19.582 & 4.53344 \\
\hline
\end{tabular}





Fig. 8 a, b SEM micrograph for pure PVA film
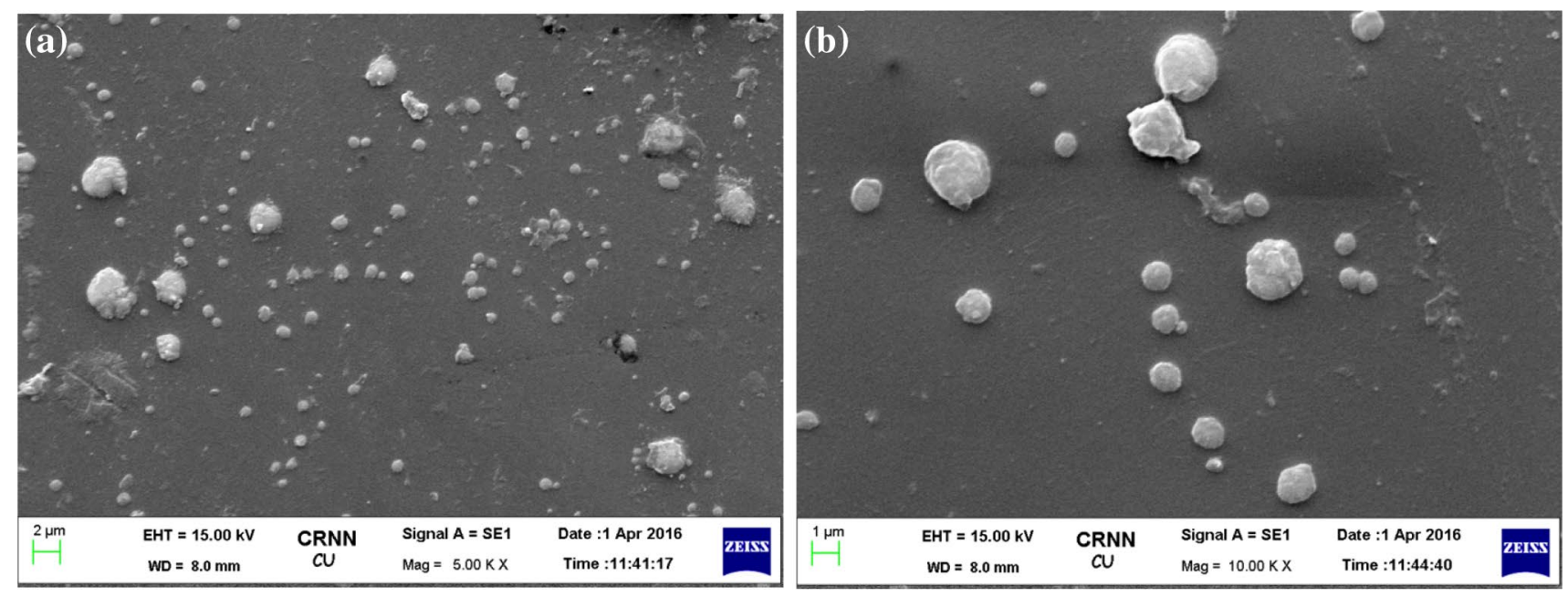

Fig. 9 a, b SEM micrograph for PVARM8
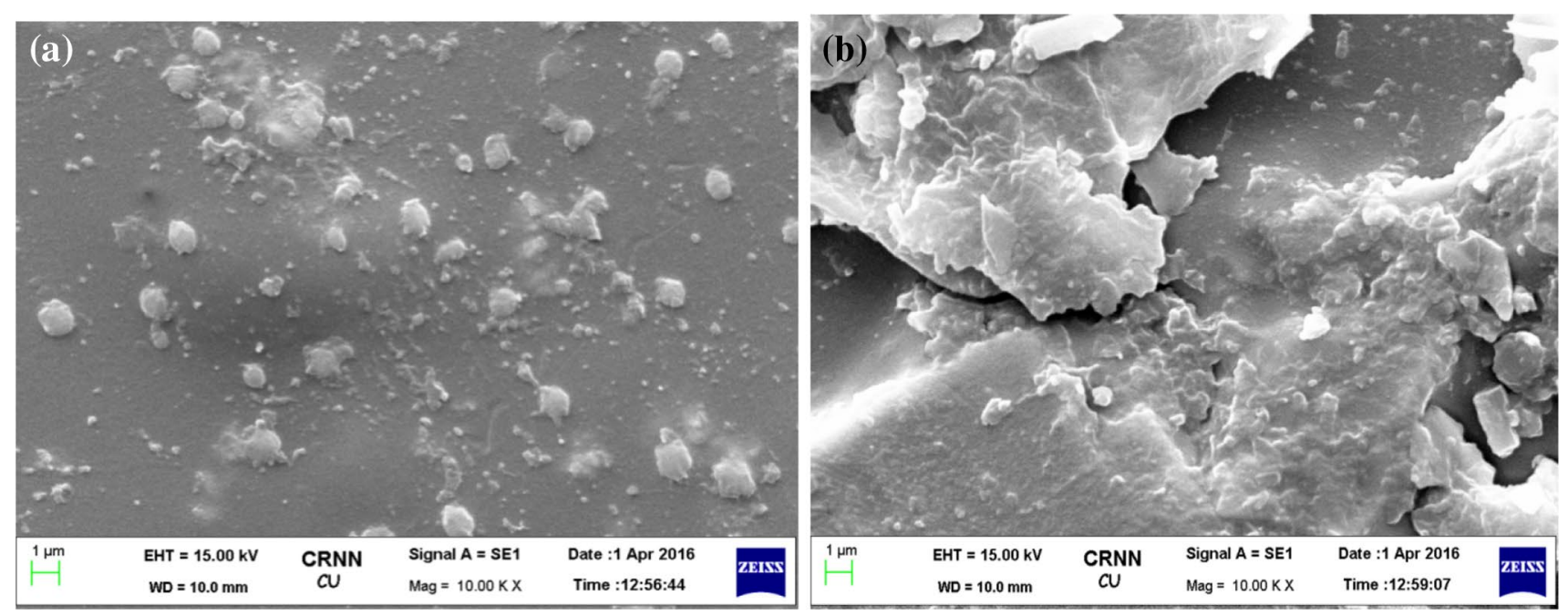

Fig. 10 a, b SEM micrograph for PVARM20

SN Applied Sciences 



Fig. 11 a, b SEM micrograph for PVARM8C
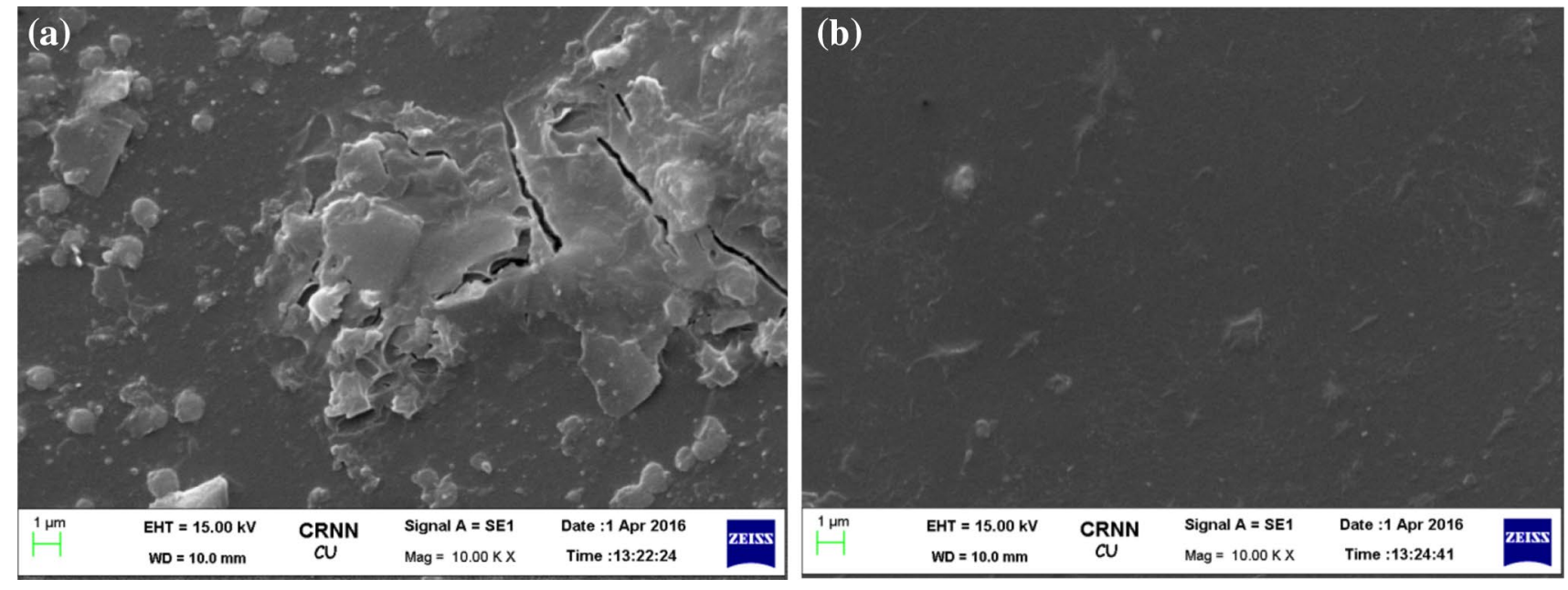

Fig. 12 a, b SEM micrograph for PVARM20C

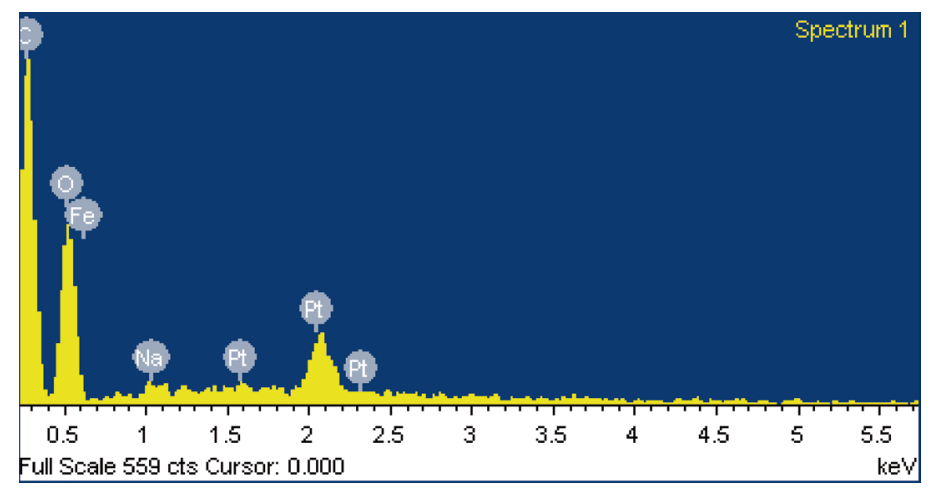

\begin{tabular}{l|ll}
\hline Element & Weight $\%$ & Atomic\% \\
& & \\
C K & 48.52 & 57.51 \\
O K & 47.42 & 42.20 \\
Pt M & 4.06 & 0.30 \\
Totals & 100.00 & \\
\hline
\end{tabular}

Fig. 13 EDX for pure PVA film 


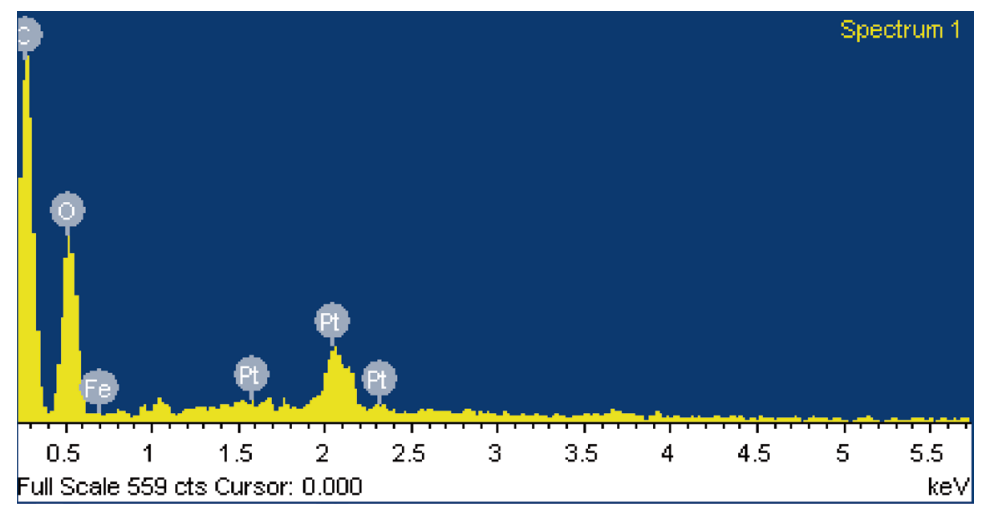

\begin{tabular}{l|ll}
\hline Element & Weight\% & Atomic\% \\
C K & 49.85 & 59.86 \\
O K & 43.85 & 39.53 \\
Fe K & 0.80 & 0.21 \\
Pt M & 5.51 & 0.41 \\
Totals & 100.00 & \\
\hline
\end{tabular}

Fig. 14 EDX for PVARM20

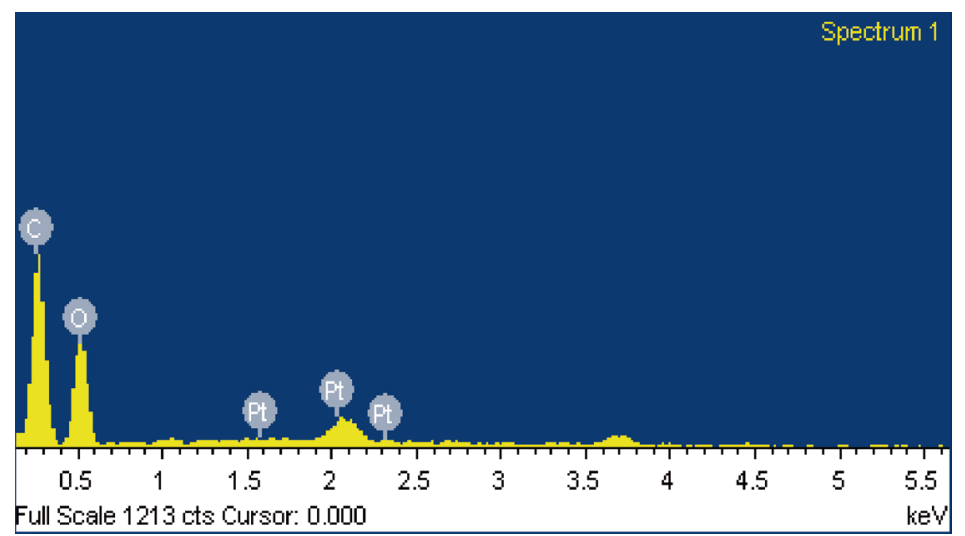

\begin{tabular}{l|ll}
\hline Element & Weight\% & Atomic\% \\
C K & 49.37 & 59.56 \\
O K & 43.42 & 39.33 \\
Na K & 0.80 & 0.51 \\
Fe K & 0.70 & 0.18 \\
Pt M & 5.71 & 0.42 \\
Totals & 100.00 & \\
\hline
\end{tabular}

Fig. 15 EDX for PVARM20C

Figure 18 showed that as the red mud amount increases in the PVA composite the boiling water resistance was increased. According to Table 2, the percentage of increase was 504.27 and 548.51 without and with SLS respectively. The hydrothermal stability of the film directly depends upon the number and the strength of the cross-links and the hydrogen bond present in the composite. The loading of red mud increases the strength of the cross-links and $\mathrm{H}$ - bonding at the interface with $\mathrm{Fe}_{2} \mathrm{O}_{3}, \mathrm{SiO}_{2}$, etc. Hence, more external energy necessary to break these additional cross-links, so boiling resistance increases. In the presence of compatibilizer, the bond strength is slightly higher so it requires more external energy to break the bonds for

Table 5 Element content for the external surface of neat PVA film and PVA composites from EDX

\begin{tabular}{lllll}
\hline & Carbon wt\% & Oxygen wt\% & Iron wt\% & Sodium wt\% \\
\hline PVA & 48.52 & 47.42 & - & - \\
PVARM20 & 49.85 & 43.85 & 0.80 & - \\
PVARM20C & 49.37 & 43.42 & 0.70 & 0.80 \\
\hline
\end{tabular}

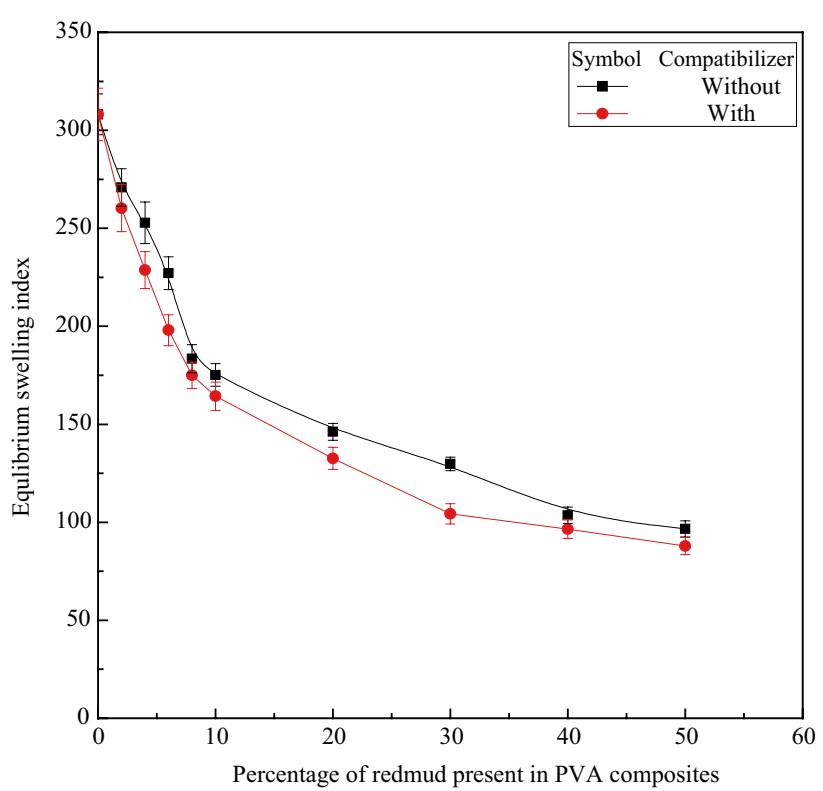

Fig. 16 Study of the swelling index of the composite films 


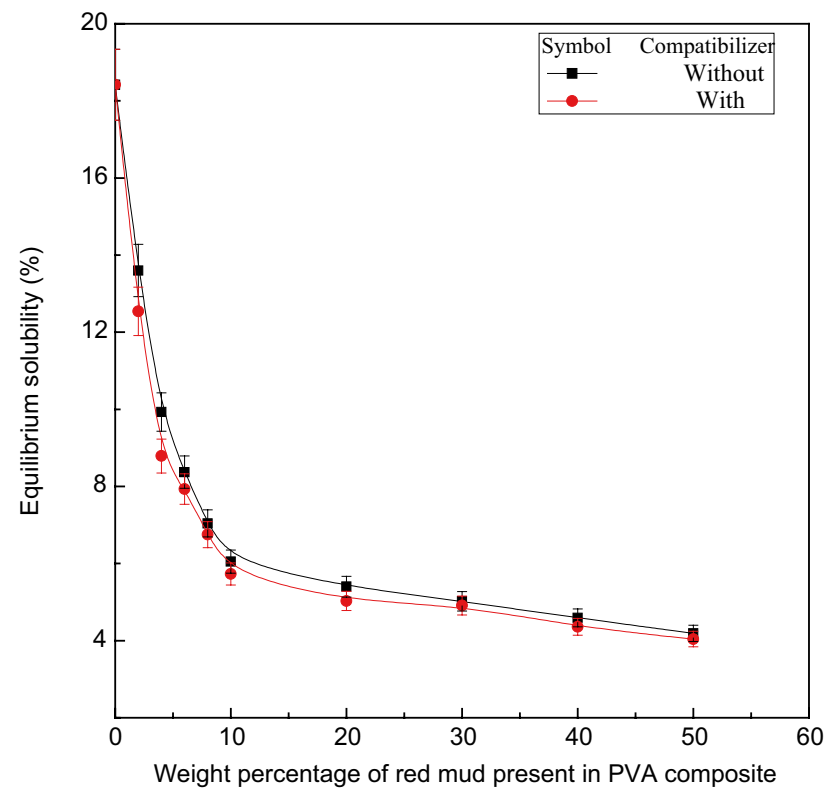

Fig. 17 Study of sobilulity of the composite films

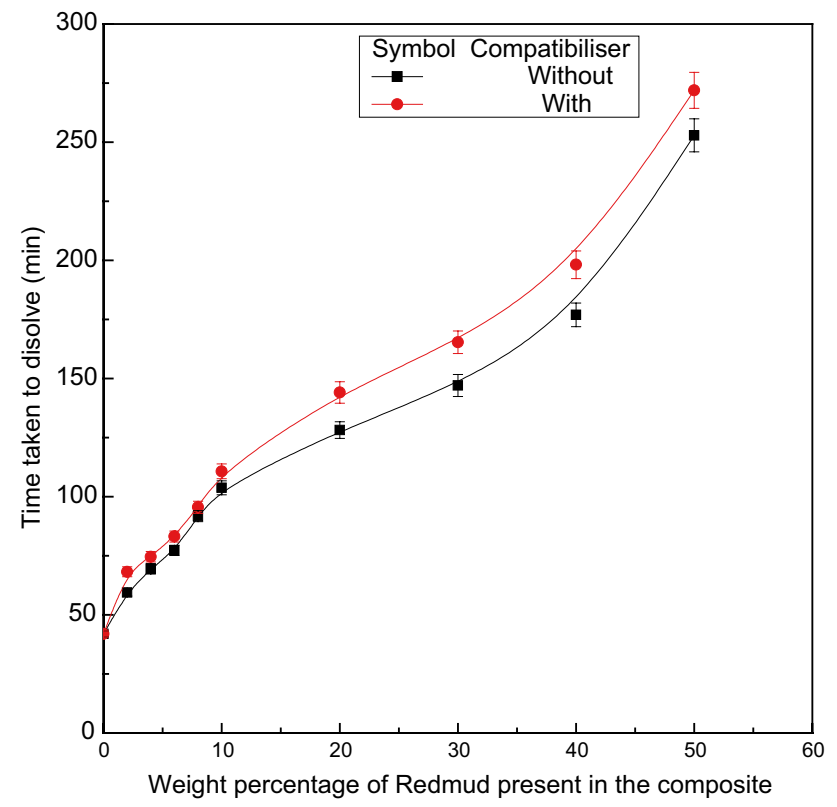

Fig. 18 Study of the boiling water resistance of the composite films

solubilization. Researchers also observed the addition of nano-clay and nano-SiO $\mathrm{S}_{2}$ to the PVA composites would enhance the water resistance compared to pure PVA film [51-53].

\subsection{Mechanical property}

The bonding ability between the matrix and reinforcing phase is one of the key factors in deciding the properties of a composite material. Tensile strength (TS), percentage of elongation at break (E\%) and Young's modulus (YM) of the PVA, PVARM and PVARMC films are shown in Table 6 and Figs. 19, 20 and 21 respectively. The resistance of the film to direct pull is a measure of tensile strength which is an important parameter for various applications of the composites. It was observed from Fig. 10 that tensile strength was almost equal for PVA, PVARM2, and PVARM6 but decrease for PVARM 10 and again increase and decrease for $30 \%$ and $50 \%$ loading of red mud respectively. In the presence of SDS in all the above composition, the tensile strength was increased significantly. Compare to pure PVA tensile strength was increased greatly for PVARM2C and PVARM10C. The composites with $6 \%, 20 \%$ and $50 \%$ loading of red mud and SDS had the greater tensile strength, and it was increased by $2.45 \%$ and $194.88 \%$ without and with SLS respectively compared to pure PVA film.

Percentage of total elongation at fracture of the composites was decreased as wt\% content of red mud was increased as shown in Fig. 11. Due to the incorporation of SDS in the composites, the above physical quantity was further reduced. The percentage of reduction was 84.81 and 98.07 for the two batches.

Young modulus of the PVA/red mud composites increases as filler amount is increased. For PVA/RM/SDS composites Young's modulus firstly increased up to $10 \mathrm{wt} \%$ of the filler content and then decreased with the increase of the filler amount. The maximum percentages of increase were 659.74 and 4336.25 for the two types of composites.

The increase of TS and the decrease of E\% with the loading of red mud irrespective of the compatibilizer is the effect of the formation of the interfacial interaction. The molecular chain mobility of PVA restricts by the interfacial interaction between PVA and red mud molecule. The increase of mechanical strength of the films compared to pure PVA is the cause of the interfacial interaction between the different molecules. Percentage of elongation at break has decreased due to the fixing between PVA chain and solid filler particle red mud which rendered them smaller flexibility against the load. So at the higher red mud load on the composite, the matrix stiffness is improved due to the formation of molecular assemblies in the matrix by the presence of dispersed red mud phase in the laminated form. This can also be seen from the SEM of the PVA and PVA-red mud composite films shown in Figs. 8, 9, 10, 11 and 12.

PVA is a highly polar matrix in the generation of intraand inter-molecular hydrogen bonding among the $-\mathrm{OH}$ and $-\mathrm{COOCH}_{3}$ groups. Due to the incorporation of red mud in the composites, the presence of $-\mathrm{OH}$ groups on the particle surface may take part in the generation of hydrogen bonding between PVA and red mud. The strength of the composites depends on the degree of 
Table 6 Data for mechanical properties of different Neat PVA film and different composites

\begin{tabular}{|c|c|c|c|c|c|c|c|}
\hline \multirow[t]{2}{*}{ Sl. no } & \multirow{2}{*}{$\begin{array}{l}\text { Wt } \% \\
\text { of red } \\
\text { mud }\end{array}$} & \multicolumn{2}{|c|}{ Tensile strength } & \multicolumn{2}{|c|}{ Elongation at break (\%) } & \multicolumn{2}{|c|}{ Young's modulus } \\
\hline & & Without SDS & With SDS & Without SDS & With SDS & Without SDS & With SDS \\
\hline 1 & 0 & 23.66215866 & - & 307.0842762 & - & 72.35181755 & $5-$ \\
\hline 2 & 2 & 22.71289696 & 58.78683575 & 236.2120991 & 29.56672132 & 95.58607426 & 52687.920327 \\
\hline 3 & 6 & 22.71021776 & 51.7838907 & 276.7690167 & 19.22225088 & 92.91139824 & 4 2795.189264 \\
\hline 4 & 10 & 15.98293038 & 69.77544016 & 152.2190958 & 49.10533233 & 87.39136616 & 63209.71758 \\
\hline 5 & 30 & 24.24081727 & 60.41839833 & 96.72225451 & 16.41475769 & 388.277916 & 1584.321558 \\
\hline 6 & 50 & 17.62066382 & 47.18686077 & 46.65246763 & 5.913293295 & 549.6825899 & 2176.763732 \\
\hline
\end{tabular}
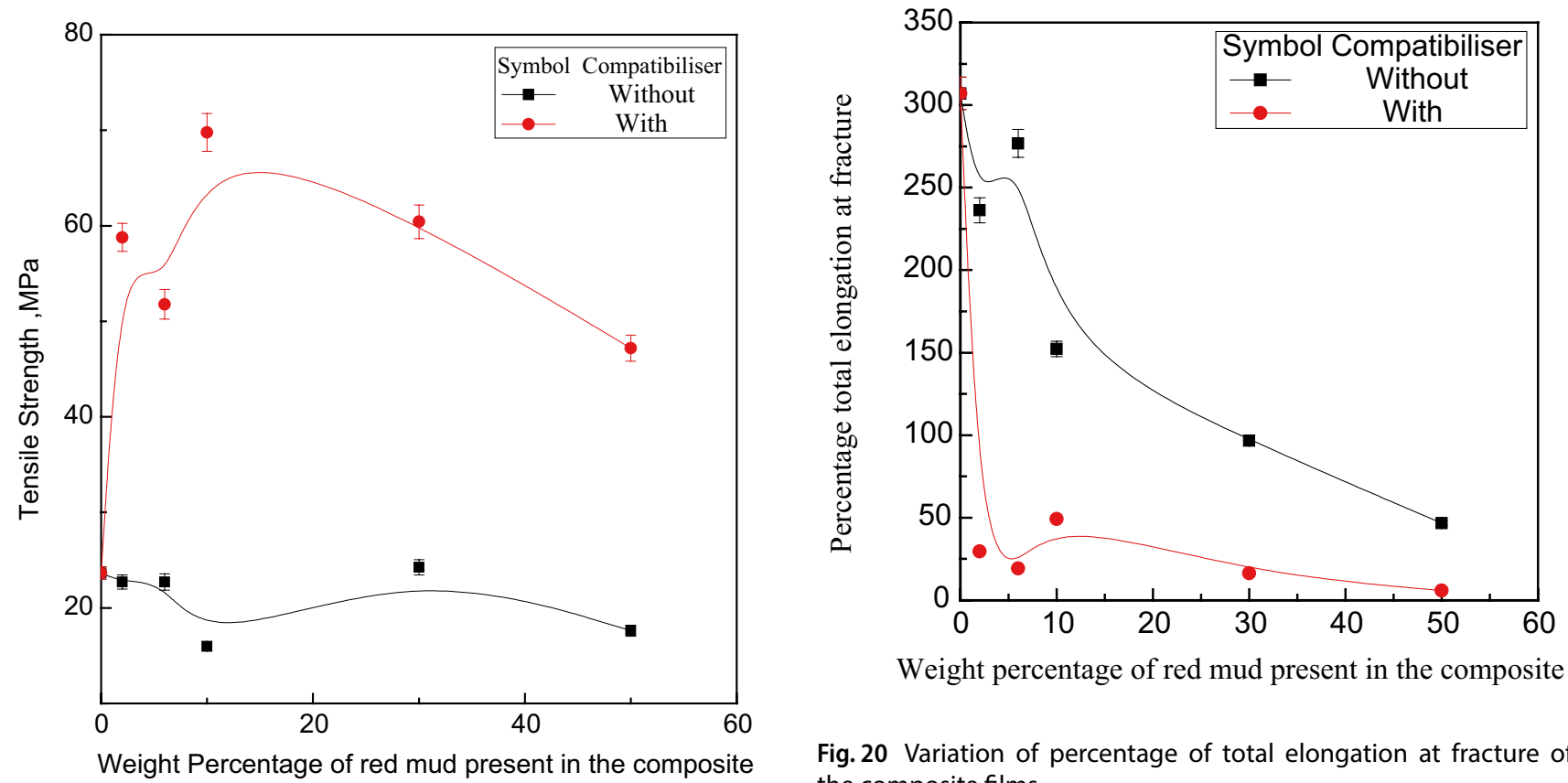

Weight percentage of red mud present in the composite

Fig. 20 Variation of percentage of total elongation at fracture of the composite films

improves with the addition of red mud and also SDS. Lopez et al. reported that in TGA thermogram there were three degradation steps in three different temperatures ranges [54]. The first weight loss of about $10 \%$ was due to the vaporization of the trapped solvent or the release of absorbed moisture. It was happened from temp 50 to $150{ }^{\circ} \mathrm{C}$ and was not dependent on the composition of the samples. There were also physically and chemically bound water in the virgin PVA and PVA composite. Physically bound water or free water acts as a plasticizing effect and also improving the movement of PVA chain; hence, the crystallinity decrease in the matrix. The chemically bound water disrupts the intra- and inter-molecular hydrogen bonding in the matrix and also form new hydrogen bonds [55]. Dehydration reaction occurs on the chain of the polymer and formation of volatile products were the cause of second weight loss which was about $70 \%$ between the temperatures 250 and $350{ }^{\circ} \mathrm{C}$. The
The TGA thermograms of PVA, PVARM20 \& PVARM20C were compared in Fig. 22 and Table 7. Thermal stability

\section{SN Applied Sciences}




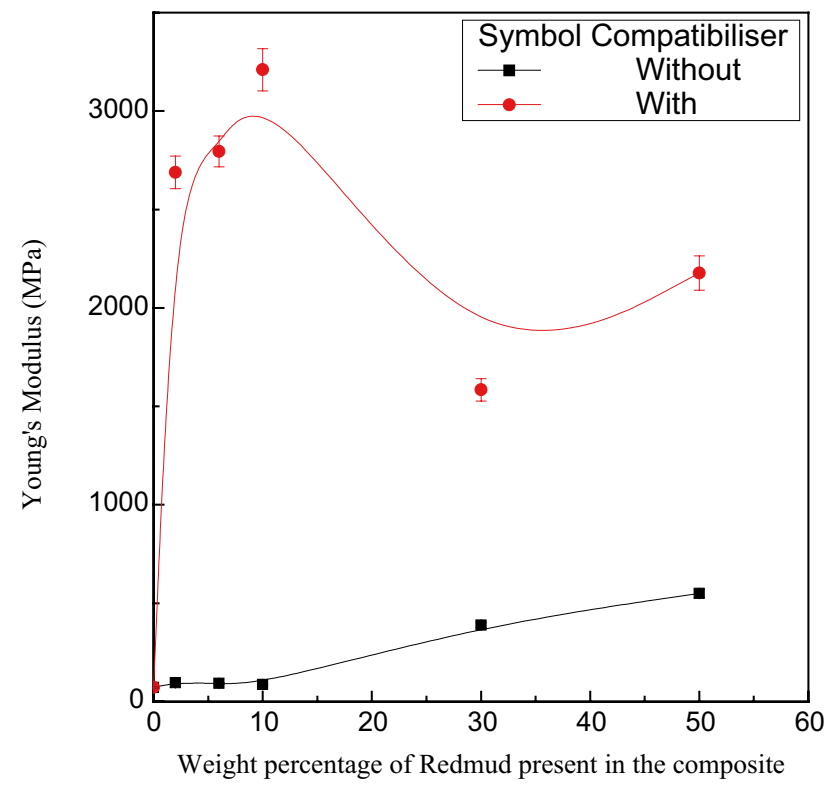

Fig. 21 Variation of Young's modulus of the composite films

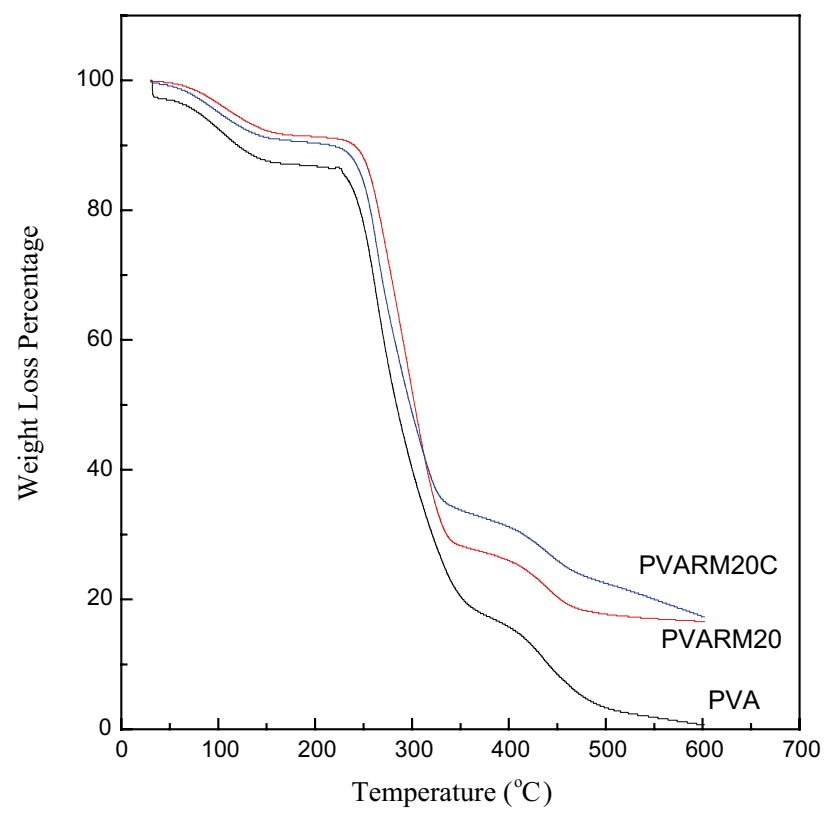

Fig. 22 TGA analysis for PVA composite films thermal degradation temperature was slightly shifted to the higher temperature due to the incorporation of red mud and compatibilizer. Third weight loss which is about $90 \%$, happened from temperature 400 to $500{ }^{\circ} \mathrm{C}$ due to the degradation of the polyene residues to yield carbon and hydrocarbons, and also to cleavage backbone of PVA composite or the decomposition of carbonaceous matter [56]. The loss of weight was greater for the loading of red mud in the films as illustrated in Table 7. According to the table, it was also shown that the weight percentage at $600{ }^{\circ} \mathrm{C}$ that is the residual weight was greater in PVA red mud composite compare to virgin PVA film and most significant in PVA red mud composite with the compatibilizer. Hu et al. reported that the thermal stability of the PVA/starch and PVA/starch/g-PLA composites were superior to the virgin PVA film [57]. Remaining weight was increased with increasing silica nanoparticles which was reported by Jia et al. [58].

\section{Conclusions}

PVA-red mud organic-inorganic composite films were successfully prepared by using the sol-gel process and with $2-50 \mathrm{wt} \%$ of red mud loading. Effects of sodium lauryl sulfate (SLS) were established for the composite films. UV-Vis study established that transparencies of the composites were decreased with the increase of red mud loading in the composites. FTIR spectra show about the different functional groups present in the composites. In XRD study $2 \theta$ value of all the composites was less than that of the neat PVA film which proved the higher percentage of crystallinity of neat PVA film compared to other composites.

The degree of swelling and solubility of PVARMSLS composite films was decreased by $71.48 \%$ and $78.07 \%$ respectively and again boiling water resistance was increased by $548.51 \%$ compared to neat PVA film. So these films had greater hydrothermal stability and can be used in the adsorption process of heavy metals removal from wastewater. Tensile strength and Young's modulus of the composite were increased by $194.88 \%$ and $4336.25 \%$ respectively, and $98.07 \%$ decreased the percentage of
Table 7 Variation of weight percentage with temperature and temperature with weight percentage in TGA graph for different samples

\begin{tabular}{|c|c|c|c|c|c|c|c|}
\hline \multirow[t]{2}{*}{ Temp. $\left({ }^{\circ} \mathrm{C}\right)$} & \multicolumn{3}{|c|}{ Weight percentage } & \multirow[t]{2}{*}{ Wt\% } & \multicolumn{3}{|c|}{ Temperature $\left({ }^{\circ} \mathrm{C}\right)$} \\
\hline & PVA & PVARM20 & PVARM20C & & PVA & PVARM20 & PVARM20C \\
\hline 100 & 92.49 & 96.51 & 95.07 & 80 & 246.59 & 264.71 & 257.23 \\
\hline 200 & 86.85 & 91.27 & 90.36 & 60 & 270.95 & 290.03 & 282.21 \\
\hline 300 & 40.14 & 51.83 & 49.04 & 40 & 300.22 & 315.49 & 318 \\
\hline 400 & 15.72 & 26.00 & 31.26 & 30 & 321 & 336.5 & 414.47 \\
\hline 500 & 3.29 & 17.8 & 22.48 & 25 & 333.43 & 411.9 & 460.34 \\
\hline 600 & 0.704 & 16.58 & 17.34 & 20 & 352 & 452.81 & 549.53 \\
\hline
\end{tabular}


elongation at break (E\%) compare to neat PVA film. These results established that in the presence of red mud and SLS the mechanical strength of the composites enhanced. TGA analysis proved that the higher thermal resistance of the PVARMSLS composites compares to pure PVA film. Chemical, thermal and mechanical properties of PVARMSLS composite films were improved for its utility in food packaging, biodegradable packaging, coating, and textile industries.

\section{Compliance with ethical standards}

Conflict of interest The authors declare they have no conflict of interest.

\section{References}

1. López DD, Guillén MM, Gullon IM, Quesada JCG, Montalbán MG (2018) Study of the behavior of biodegradable starch/polyvinyl alcohol/rosin blends. Carbohydr Polym 202:299-305

2. Mittal A, Garga S, Kohlia D, Maitib M, Janac AK, Bajpaia S (2016) Effect of cross linking of PVA/starch and reinforcement of modified barley husk on the properties of composite films. Carbohydr Polym 151:926-938

3. Heidarian P, Behzad T, Sadeghi M (2017) Investigation of cross-linked PVA/starch biocomposites reinforced by cellulose nanofibrils isolated from aspen wood sawdust. Cellulose 24(8):3323-3339

4. Priya B, Gupta VK, Pathania D, Singha AS (2014) Synthesis, characterization and antibacterial activity of biodegradable starch/ PVA composite films reinforced with cellulosic fibre. Carbohydr Polym 109:171-179

5. Yoon SD, Park MH, Byun HS (2012) Mechanical and water barrier properties of starch/PVA composite films by adding nano-sized poly(methyl methacrylate-co-acrylamide) particles. Carbohydr Polym 87(1):676-686

6. Wang Z, Qiao X, Sun K (2018) Rice straw cellulose nanofibrils reinforced poly(vinyl alcohol) composite films. Carbohydr Polym 197:442-450

7. Wang W, Zhang H, Jia R, Dai Y, Dong H, Hou H, Guo Q (2018) High performance extrusion blown starch/polyvinyl alcohol/ clay nanocomposite films. Food Hydrocoll 79:534-543

8. Masuhiro T, Giuliano F, John SC (1994) Structure and compatibility of poly (vinyl alcohol)_silk fibroin (PVA/SA) blend films. J Polym Sci B Polym Phys 32(2):243-248

9. Liua B, Han Xua H, Zhaob H, Liub W, Zhaoa L, Li Y (2017) Preparation and characterization of intelligent starch/PVA films for simultaneous colorimetric indication and antimicrobial activity for food packaging applications. Carbohydr Polym 157:842-849

10. Abdelkader KA, Anwar Z (2006) Spectrocopic studies of polyvinylalcohol. J Appl Polym Sci 2:1146-1151

11. Ray S, Okamoto M (2003) Polymer/layered silicate nanocomposites: a review from preparation to processing. Prog Polym Sci 28(11):1539-1641

12. Madyan OA, Fan M, Feo L, Hui D (2016) Enhancing mechanical properties of clay aerogel composites: an overview. Compos B Eng 98:314-329

13. Toyoda N, Yamamoto T (2018) Dispersion of carbon nanofibers modified with polymer colloids to enhance mechanical properties of PVA nanocomposite film. Coll Surf A Physicochem Eng Asp 556:248-252

14. Akhavan A, Khoylou F, Ataeivarjovi E (2017) Preparation and characterization of gamma irradiated Starch/PVA/ZnO nanocomposite films. Rad Phys Chem 138:49-53

15. Purwar R, Sharma S, Sahoo P, Srivastava CM (2015) Flexible sericin/polyvinyl alcohol/clay blend films. Fibers Polym 16(4):761-768

16. Chiellini EP, Cinelli P, Imam SH, Mao I (2001) Composite films based on bio related agro-industrial waste and poly (vinyl alcohol): preparation and mechanical properties characterization. Biomacromole 2(3):1029-1037

17. He P, Bai S, Wang Q (2016) Structure and performance of poly(vinyl alcohol)/wood powder composite prepared by thermal processing and solid state shear milling technology. Compos Part B Eng 99:373-380

18. Kaler V, Pandel U, Duchaniya RK (2018) Development of TiO2/ PVA nanocomposites for application in solar cells. Mater Today Proc 5:6279-6287

19. Magalhães MS, Filho RDT, Fairbairn EMR (2015) Thermal stability of PVA fiber strain hardening cement-based composites. Constr Build Mater 94:437-447

20. Tan LS, Mchugh AJ (1996) The role of particle size and polymer molecular weight in the formation and properties of an organoceramic composite. J Mater Sci 31(14):3701-3706

21. Lee ES, Kim YO, Ha YM, Lim D, Jung YC (2018) Antimicrobial properties of lignin-decorated thin multi-walled carbon nanotubes in poly(vinyl alcohol) nanocomposites. Eur Polym J 105:79-84

22. Ounkaew A, Kasemsiri P, Kamwilaisak K, Saengprachatanarug K, Mongkolthanaruk W, Souvanh M, Pongsa U, Chindaprasirt P (2018) Polyvinyl alcohol (PVA)/starch bioactive packaging film enriched with antioxidants from spent coffee ground and citric acid. J Polym Environ 26:3762-3772

23. Shehap AM, Elsayed KA, Akil DS (2017) Optical and structural changes of $\mathrm{TiO}_{2} /$ PVA nano composite induced laser radiation. Phys E Low-Dimens Syst Nanostructures 86:1-9

24. Guisasola CG, Greus AR (2018) Dielectric relaxations and conductivity of cross-linked PVA/SSA/GO composite membranes for fuel cells. Polym Test 67:55-67

25. Bhat AH, Banthia AK (2007) Preparation and characterization of poly(vinyl alcohol)-modified red mud composite materials. J Appl Polym Sci 103(1):238-243

26. Grjotheirn K, Welch BJ (1998) Aluminium smelter technology, a pure and applied approach, 2nd edn. Verlagcdon, Dusseldorf

27. Tyan HL, Liu YC, Wei KH (1999) Thermally and mechanically enhanced clay/polyimide nanocomposite via reactive organoclay. Chem Mater 11(7):1942-1947

28. Rahman MR, Hui JLC, Hamdan SB (2018) Polyvinyl alcohol/silica/ clay nanocomposites: effect of clay on surface morphology, electrical and thermo-mechanical properties. Ch. 4 pp 45-57 in Silica and Clay Dispersed. Polymer Nanocomposites, Ed. Md. R. Rahman

29. Gilman JW, Jackson CL, Morgan AB, Hayyis RJR, Manias E, Giannelis EP, Wuthenow M, Hilton D, Philips SH (2000) Flammability properties of polymer-layered-silicate nanocomposites polypropylene and polystyrene nano composites. Chem Mater 12(7):1866-1873

30. Yeh JM, Liou SJ, Lai CY, Wu PC, Tsai TY (2001) Enhancement of corrosion protection effect in polyaniline via formation of polyaniline-clay nanocomposite materials. Chem Mater 13(3):1131-1136

31. Devikala S, Kamaraj P, Arthanareeswari M (2018) Corrosion resistance behavior of $\mathrm{PVA} / \mathrm{TiO}_{2}$ composite in $3.5 \% \mathrm{NaCl}$. Mater Today Proc 5:8672-8677

32. Yeh JM, Liou SJ, Lin CY, Cheng CY, Chang YW, Lee KR (2002) Anti corrosively enhanced pmma-clay nano composite materials 
with quaternary alkyl phosphonium salt as an intercalating agent. Chem Mater 14(1):154-161

33. Wang Z, Pinnavaia TJ (1998) Nanolayer reinforcement of elastomeric polyurethane. Chem Mater 10(12):3769-3771

34. Kasliwal P, Sai PST (1999) Enrichment of titanium dioxide in red mud: a kinetic study. Hydrometallurgy 53(1):73-87

35. Chand N, Hashmi SAR (1999) Effect of red mud addition on abrasive wear rate of isotactic polypropylene low density polyethylene blend under low density conditions. J Sci Ind Res 58:795-798

36. Chand N, Hashmi SAR (1999) Effect of addition of polycarbonate on sheared flow of red mud-filled isotactic polypropylene. Bull Mater Sci 22(4):801-804

37. Pradhan J, Das SN, Thakur RS (1999) Adsorption of hexavalent chromium from aqueous solution by using activated red mud. J Colloid Interface Sci 217(1):137-141

38. Bhat AH, Banthia AK (2008) Mechanical and dynamic analysis of poly (vinyl alcohol)- modified inorganic filler composite. Polym Plast Tech Eng 47(2):115-121

39. Liang J, Chen R (2018) Impact of cross-linking mode on the physical properties of zein/PVA composite films. Food Pack Shelf Life 18:101-106

40. Singha AS, Kapoor H (2014) Effects of plasticizer/cross-linker on the mechanical and thermal properties of starch/PVA blends. Iran Polym J 23(8):655-662

41. Ahmad J, Deshmukh K, Habib M, Hägg MB (2014) Influence of $\mathrm{TiO}_{2}$ nano particles on the morphological, thermal and solution properties of $\mathrm{PVA} / \mathrm{TiO}_{2}$ nano composite membranes. Arab J Sci Eng 39(10):6805-6814

42. Halder M, Das AK, Meikap AK (2018) Effect of BiFeO3 nanoparticle on electrical, thermal and magnetic properties of polyvinyl alcohol (PVA) composite film. Mater Res Bull 104:179-187

43. Qian XF, Yin J, Huang JC, Yang YF, Guo XX, Zhu ZK (2001) The preparation and characterization of $\mathrm{PVA} / \mathrm{Ag}_{2} \mathrm{~S}$ nano composite. Mater Chem Phys 68(1-3):95-97

44. Wang H, Fang P, Chen Z, Wang S (2007) Synthesis and characterization of CdS/PVA nano composite film. Appl Surf Sci 253:8495-8499

45. Goutam A, Ram S (2010) Preparation and thermomechanical properties of Ag-PVA nano composite films. Mater Chem Phys 119:266-271

46. Yun YH, Kim ES, Shim WG, Yoon SD (2018) Physical properties of mungbean starch/PVA bionanocomposites added nanoZnS particles and its photocatalytic activity. J Ind Eng Chem 68:57-68

47. Mallakpour S, Naghdi M (2016) Evaluation of nanostructure, optical absorption, and thermal behavior of poly(vinyl alcohol)/poly ( $\mathrm{N}$-vinyl-2-pyrrolidone) based nanocomposite films containing coated $\mathrm{SiO}_{2}$ nano particles with citric acid and I (+)-ascorbic acid. Polym Compos 39(6):2012-2018

48. Rahman MM, Afrin S, Haque P (2014) Characterization of crystalline cellulose of jute reinforced poly (vinyl alcohol) (PVA) biocomposite film for potential biomedical applications. Prog Biomater 3:23

49. El-Hefian EA, Nasef MM, Yahaya AH (2010) The preparation and characterization of chitosan/poly (vinyl alcohol) blended films. J Chem 7(4):1212-1219

50. Mathew S, Snigdha S, Mathew J, Radhakrishnan EK (2018) Poly(vinyl alcohol): montmorillonite: boiled rice water (starch) blend film reinforced with silver nanoparticles; characterization and antibacterial properties. Appl Clay Sci 161:464-473

51. Cyras VP, Manfredi LB, Ton-That MT, Vázquez A (2008) Physical and mechanical properties of thermoplastic starch/montmorillonite nanocomposite films. Carbohydr Polym 73(1):55-63

52. Dean K, Yu L, Wu DY (2007) Preparation and characterization of melt-extruded thermoplastic starch/clay nanocomposites. Compos Sci Tech 67(3-4):413-421

53. Xiong HG, Tang SW, Tang HL, Zou P (2008) The structure and properties of a starch-based biodegradable film. Carbohydr Polym 71(2):263-268

54. Lopez D, Cendoya I, Torres F, Tejada J, Mijangos C (2001) Preparation and characterization of poly (vinyl alcohol) based magnetic composites. 1. Thermal and mechanical properties. J Appl Polym Sci 82(13):3215-3222

55. Forne AN, Panaitescu DM, Donescu D, Spataru Cl, Radovici C, Trusca R, Somoghi R (2011) Preparetion and characterization of PVA composites with cellulose nanofibers obtained by ultrasonication. BioResources 6(1):487-512

56. Lee SY, Mohan DJ, Kang IA, Doh GH, Lee S, Han SO (2009) Nanocellulose reinforced PVA Composite films: effects of acid treatment and filler loading. Fibers Polym 10(1):77-82

57. Hu Y, Wang Q, Tang M (2013) Preparation and properties of starch-g-PLA/poly(vinyl alcohol) composite film. Carbohydr Polym 96(2):384-388

58. Jia X, Li Y, Cheng Q, Zhang S, Zhang B (2007) Preparation and properties of polyvinyl alcohol/silica nanocomposites derived from copolymerization of vinyl silica nanoparticles and vinyl acetate. Eur Polym J 43(4):1123-1131

Publisher's Note Springer Nature remains neutral with regard to jurisdictional claims in published maps and institutional affiliations. 